\title{
METODE PENILAIAN HARGA WAJAR SAHAM PERUSAHAAN MANUFAKTUR YANG TERCATAT DI BURSA EFEK INDONESIA
}

\author{
Erna Retna Rahadjeng \\ Fakultas Ekonomi Universitas Muhammadiyah Malang \\ Emai: erna_retna@yahoo.co.id
}

\begin{abstract}
Abstraksi
Penelitian ini bertujuan bagaimana menentukan harga saham dalam kondisi overvalue atau undervalue, selain juga untuk mengetahui dan menguji secara empiris metode yang digunakan untuk menentukan harga wajar saham perusahaan manufaktur dengan metode buffert dan Benyamin. Untuk menjawab tujuan di atas akan dilakukan secara bertahap yaitu untuk membuktikan bahwa harga saham dalam kondisi overvalue atau undervalue digunakan analisis fundamental dengan mengukur tiga variabel yaitu EPS, PER, dan PBV, sedangkan untuk menjawab tujuan kedua yaitu untuk menentukan dan menguji secara empiris metode yang digunakan untuk menentukan harga wajar saham agar terbentuk metode yang baru. Berdasarkan hasil analisis data diperoleh bahwa untuk menilai harga wajar saham dengan metode Fundamental, Gordon dan Benjamin masih perlu dilakukan pembuktian metode karena berdasarkan hasil penelitian masih belum ada kesamaan nilai wajar saham pada perusahaan manufaktur selama tahun 2000 sampai 2007. Hal ini penulis mencoba membuat metode untuk menghitung nilai wajar saham dengan metode analisis fundamental, Gordon, dan Benjamin yang dikombinasikan. Harapan peneliti agar terbentuknya harga wajar saham dapat membantu investor dalam berinvestasi di pasar modal, yaitu apabila harga mendekati atau sama dengan nilai intrinsiknya, maka investor akan membeli, tetapi apabila harga pasar lebih besar dibanding nilai intrinsiknya maka investor akan menjual sahamnya.
\end{abstract}

\begin{abstract}
This study aims to determine how the stock prices in a state overvalue or undervalue, as well as to identify and empirically examine the methods used to determine the fair price of the stock of manufacturing companies and Fundamental analysis, Benjamin, Gordon method. To answer the above purpose will be done in stages that is to prove that the price of shares in the conditions used overvalue or undervalue the fundamental analysis by measuring three variables: EPS, PER, and PBV, whereas to answer the second objective is to determine and empirically examine the methods used for determining the fair price of the stock in order to form the new method. Based on the result of the analysis that in order to assess the fair price of the stock with Fundamental
\end{abstract}


methods, Gordon and Benjamin still needs to be done because the method of proof based on the research there is still no common shares in the fair value of manufacturing companies during the years 2000 until 2007. This writer tried to make the method for calculating the fair value of stock with the method of fundamental analysis, Gordon, and Benjamin combined. Researchers Hope to the formation of reasonably priced stocks can help investors to invest in capital markets, if when the price is nearly equal to its intrinsic value, then the investor will buy, but if the market price is greater than its intrinsic value, the investor will sell the shares.

Pasar modal di Indonesia mulai diaktifkan kembali di Indonesia sejak tanggal 10 Agustus 1977. Tujuan Pasar Modal di Indonesia adalah untuk mengerahkan dana, dari masyarakat guna disalurkan ke sektor-sektor yang lebih produktif, serta ikut mewujudkan pemerataan pendapatan melalui pemilikan saham-saham perusahaan. Tujuan ini secara bertahap dicapai dengan semakin banyaknya jumlah perusahaan yang go-publik dalam memasyarakatkan sahamnya, semakin banyaknya jenis dan jumlah surat berharga yang diperjual belikan serta bertambah banyaknya lembaga-lembaga yang mendukung terselenggaranya kegiatan pasar modal tersebut.

Perkembangan pasar modal selain menambah sumber-sumber pengerahan dana masyarakat di luar perbankan juga, merupakan sumber dana, yang sangat potensial bagi perusahaan yang membutuhkan dana jangka menengah dan jangka panjang. Sedangkan bagi masyarakat kehadiran pasar modal di Indonesia merupakan tambahan alternatif investasi yang selama ini masih dirasakan masih sangat terbatas. Di negara-negara yang telah maju, investasi dana melalui pembelian saham dan obligasi pada umumnya dinilai lebih menarik karena dapat memberikan keuntungan yang lebih besar yang diperoleh dari perubahan harga surat-surat berharga tersebut.

Posisi investor di bursa efek merupakan posisi kunci kegiatan bursa, oleh karena itu penelitian ini mengarah pada ketika investor memutuskan untuk melakukan investasi di pasar modal. Bagi sebagian orang, perdagangan efek harus diartikan sebagai kegiatan investasi. Mereka berangkat dari argumentasi bahwa semua investor adalah rasional. Keputusan investasi dari seorang investor yang 
rasional didahului oleh suatu proses analisis terhadap rariabel yang secara fundamental diperkirakan akan mempengaruhi harga efek.

Para investor di pasar modal harus menyadari, bahwa bermain di pasar modal tidak harus memberi keuntungan, tetapi kemungkinan akan terjadi sebaliknya, yaitu harus menanggung kerugian. Keuntungan maupun kerugian yang terjadi tergantung pada, kemampuan investor dalam menganalisis informasi yang ada. Dalam hal ini peranan pialang/broker adalah sangat penting dalam memberikan bantuan pada investor untuk memperoleh informasi-informasi yang dibutuhkan, sebagai pedoman untuk pembuatan analisis-analisis yang akan dilakukan.

Pengambilan keputusan investasi di bursa efek sangat dipengaruhi oleh berbagai aspek baik aspek finansial maupun aspek non finansial. Adanya, berbagai aspek yang ada peneliti mencoba mengangkat permasalahan tentang keputusan investor dalam menginvestasikan dananya, di bursa efek ditinjau dari tingkat pendidikan, jabatan dan pendapatan seseorang yang berkaitan dengan penggunaan analisis fundamental dan analisis tehnikal.

Bursa efek Indonesia merupakan tempat terjadinya, transaksi jual beli saham, yang pelakunya terdiri dari para investor baik individu maupun lembaga/organisasi. Untuk melakukan investasi di bursa efek diperlukan informasi, baik informasi akuntansi dalam hal ini menggunakan analisis fundamental maupun informasi non akuntansi dalam hal ini menggunakan analisis tehnikal. Informasi akuntansi dimaksudkan sebagai informasi yang sifatnya keuangan (financial information).

Seorang investor atau calon investor individual mengambil keputusan untuk membeli saham tertentu, sebaiknya didasari atas basil analisis saham. Tujuannya adalah untuk menentukan baik kualitas, prospek, maupun tingkat resiko dari suatu saham. Untuk itu diperlukan informasi yang cukup. Kurang atau tidak cukupnya informasi yang digunakan dalam mengananalisis prospek saham yang akan dibeli, akan menempatkan golongan ini pada kategori spekulasi. Bahkan kalau keputusan diambil tanpa dasar informasi dapat digolongkan sebagai penjudi (gambler), 
Pasar modal yang bermanfaat bagi investor mempunyai ciri sebagai berikut : a) Pasar harus efisien b) Tersedianya aturan yang melindungi investor dari penipuan, kecurangan, penggelapan atau tindak tak etis pihak yang terlibat dalam penerbitan atau perdagangan asset finansial.

Pasar yang efisien mencakup tiga pengertian yaitu: (1) harga yang terjadi di pasar modal telah mencerminkan semua informasi mengenai keadaan ekonomi dan keadaan perusahaan secara cepat dan tepat, (2) alokasi sumber daya modal yang terjadi di pasar modal adalah optimal, dan (3) biaya pengoperasian pasar modal yang tersedia tidak mahal.

Secara normatif suatu keputusan investasi yang baik adalah jika keputusan tersebut memberikan manfaat riil yang lebih besar dari pada biayanya. Dengan demikian investor dihadapkan pada suatu pemilihan alternatif untuk memilih jenis investasi yang menguntungkan. Dari sekian banyak investasi, investasi saham merupakan jenis investasi yang banyak menguntungkan daripada jenis investasi lainnya seperti misalnya investasi dalam bentuk aktiva seperti emas, perak, real estate atau investasi dalam bentuk deposito.

Investasi saham merupakan investasi yang likuid sekali, karena perubahan portofolio saham sangat cepat. Akibatnya tingkat keuntungan yang dapat diraih cukup besar dibandingkan dengan investasi lainnya yang bersifat permanen. Tetapi tingkat keuntungan yang tinggi akan dibarengi pula oleh resiko yang tinggi. Dengan kata lain, karena keputusan investasi menyangkut masa yang akan datang, maka sudah pasti investasi tersebut mengandung unsur risiko bagi investor. Umumnya risiko ada pada setiap alternatif investasi, sedangkan besar kecilnya resiko tergantung pada besar kecilnya investasi dan besar kecilnya tingkat keuntungan yang diharapkan.

Untuk mengatasi risiko hingga sekecil mungkin maka seorang investor dalam mengambil keputusan investasi saham biasanya dipengaruhi oleh latar belakang investor sendiri ditinjau dari tingkat pendidikan, tingkat jabatan, serta tingkat pendapatan yang berbeda. Adanya latar belakang yang berbeda dari setiap investor akan berpengaruh dalam membaca informasi-informasi yang diterima tentang perkembangan pasar modal, sehingga berbeda pula alasan yang dipergunakan untuk pengambilan keputusan investasi khususnya investasi saham. 
Dari latar belakang diatas maka tujuan dari penelitian ini adalah (1) membuktikan bahwa harga saham dalam kondisi overvalue atau undervalue (2) untuk mengetahui dan menguji secara empiris metode yang digunakan dalam menentukan harga wajar saham dan (3) menghasilkan konsep suatu metode menghitung harga wajar saham perusahaan manufaktur.

\section{KERANGKA KONSEPTUAL}

Adapun kerangka konseptual penelitian ini adalah:

Gambar 1.

Konsep Metode Penentuan Harga Wajar Saham

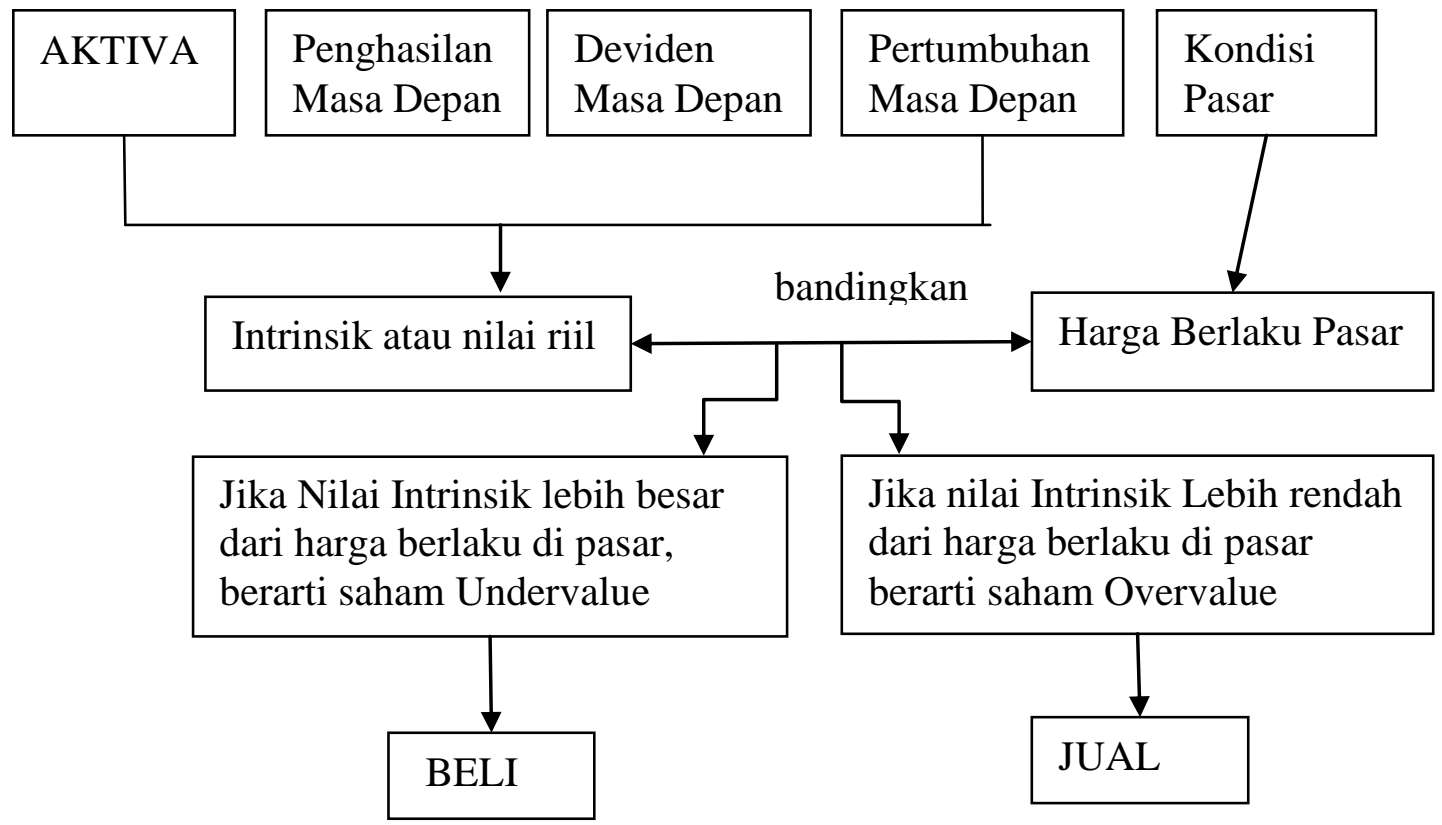

\section{METODE}

Rancangan penelitian ini terdiri dari: identifikasi dan pengukuran variabel, sumber data, sampling dan tehnik pengumpulan data, serta tehnik pengolahan data. Sesuai dengan tujuan penelitian maka akan digunakan metode untuk penentuan harga wajar saham.

\section{Identifikasi dan Pengukuran Variabel}

Nilai buku merupakan nilai saham menurut pembukuan perusahaan emiten. Nilai pasar merupakan nilai saham di pasar saham, dan nilai intrinsik merupakan nilai sebenarnya dari saham. Nilai pasar yang lebih kecil dari nilai intrinsiknya menunjukkan bahwa saham tersebut dijual dengan harga yang murah 
(undervalued. Sebaliknya nilai pasar yang lebih besar dari nilai intrinsiknya menunjukkan bahwa saham tersebut dijual dengan harga yang mahal (overvalued).

Sedangkan untuk menghitung nilai wajar saham menggunakan analisis fundamental, metode Benjamin dan Gordon.

\section{Jenis dan Sumber Data}

Jenis data dalam penelitian digunakan jenis data dokumenter, yaitu merupakan jenis data yang diperoleh dari laporan keuangan, dan laporan yang dipublikasikan, sedangkan sumber data dalam penelitian ini berupa data sekunder, dimana jenis data ini diperoleh melalui data-data yang telah disusun sebelumnya.

\section{Populasi dan Sampel}

Populasi pada penelitian ini meliputi semua perusahaan manufaktur yang tercatat di Bursa Efek Indonesia selama periode 2000-2007. Adapun sampel dalam penelitian ini ditentukan dengan metode purposive sampling dengan kriteria yang telah ditentukan peneliti yaitu perusahaan manufaktur setiap harinya aktif melakukan transaksi di bursa Efek pada tahun 2000-2007 dan laporan keuangan perusahaan tersedia selama delapan tahun berturut-turut.

\section{Analisis Data}

Untuk mengetahui harga saham dalam kondisi undervalue atau overvalue dengan cara membandingkan antara harga intrinsik dengan harga pasar. Untuk menjawab rumusan kedua digunakan metode yang ada yaitu menentukan harga wajar saham dengan berbagai metode antara lain metode fundamental, Benjamin dan Gordon yang semuanya merupakan metode penentuan harga wajar saham.

\section{Analisis Fundamental}

1. Metode PER dengan rumus: perbandingan antara harga pasar saham (market value) dengan laba per lembar saham (EPS)

Harga pasar
PER = -----------------
EPS

Price Of Stock

2. Metode PBV dengan rumus : PBV = ------------------- 
PBV ratio adalah rasio perbandingan antara harga pasar saham dan nilai buku per saham (book value per share).

Total Equity

Book Value per share $=$

Number of outstanding Shares

3. Pendekatan ROE dan ROA

Laba Bersih

ROA =

Laba Bersih

ROE = ---------------------------------

Modal Aset

4. DER

$$
\text { DER = } \begin{gathered}
\text { Total Hutang } \\
-------------- \\
\text { Modal Sendiri }
\end{gathered}
$$

\section{Metode Benjamin}

Untuk menentukan harga wajar dapat digunakan formula yang telah ditemukan Graham sebagai berikut:

$$
\mathrm{V}=\operatorname{EPS} \times(8.5+2 \mathrm{G}) \times(6.5 / \mathrm{AAA})
$$

Di mana:

$\mathrm{V}=$ Nilai intrinsik saham (harga wajar saham)

EPS $=$ Earning per Share

$8.5=\mathrm{P} / \mathrm{E}$ wajar untuk perusahaan yang tidak tumbuh labanya

$\mathrm{G} \quad=$ tingkat pertumbuhan laba jangka panjang (7 -10 tahun)

$\mathrm{BI}$ rate saat ini $=6.5 \%$.yang merepresentasikan risk-free rate dan 
AAA $=$ merepresentasikan kupon (bunga) dari obligasi korporat berkualitas tinggi.

$\begin{array}{ll}\text { AAA } & =11.625 \%(\text { Obligasi Bank Ekspor Indonesia IV Tahun } 2009 \text { Seri B }) \\ \text { G } & =17.53 \text { (data diperoleh dari reuters pada bagian long term growth rate. }\end{array}$

\section{Gordon Growth Model}

Metode Gordon ini di formulasikan:

$$
\begin{aligned}
& \mathrm{V}=(\mathrm{DPS} 1) / \text { Harga Pasar }+\mathrm{g} \\
& \mathrm{g}=\text { ROE } \mathrm{x} \text { Laba ditahan } \\
& \mathrm{g}=\text { laba ditahan }(\mathrm{ROA}+\mathrm{D} / \mathrm{E}(\mathrm{ROA}-\mathrm{I}(1+\mathrm{t}))
\end{aligned}
$$

Dimana :

DPS = Dividen yang diharapkan pemegang saham akan diterima.

DPS1 adalah dividen pertama yang diharapkan, dan akan dibayar akhir tahun ini;

$\mathrm{g}$ = Laju pertumbuhan yang diharapkan dalam dividen yang diramalkan oleh investor marjinal.

\section{PEMBAHASAN}

Untuk menjawab perumusan pertama akan digunakan ananalisis deskriptif yaitu pembahasan secara teoritis. Saham dalam kondisi undervalue atau overvalue yaitu: a) "Jika nilai intrinsik lebih besar daripada harga pasar saham saat ini, maka saham tersebut adalah undervalue sebaiknya dibeli atau tetap disimpan/ditahan, jika dimiliki, b) Jika, nilai intrinsik lebih kecil daripada harga pasar saham saat ini, maka saham tersebut adalah overvalue dan sebaiknya dihindari, dijual bila dimiliki atau jika memungkinkan dijual dalam waktu singkat, c) Jika nilai intrinsik sama dengan harga pasar saham saat ini, implikasinya terjadi keseimbangan dimana saham tersebut mempunyai nilai yang wajar (correctly valued).

Untuk menjawab rumusan kedua yaitu metode yang digunakan dalam menentukan harga wajar saham digunakan metode fundamental, metode Benjamin dan metode Gordon. 
Tabel 1.

Analisis Fundamental

\begin{tabular}{|c|c|c|c|c|c|c|c|c|c|c|c|}
\hline TAHUN & PER & PBV & EPS (Rp) & ROE & ROA & NPM & DER & $\begin{array}{l}\text { DPS } \\
\text { (Rp) }\end{array}$ & $\begin{array}{l}\text { CLOS } \\
\text { PRICE } \\
\text { (Rp) }\end{array}$ & DPY & $\mathrm{CR}$ \\
\hline \multicolumn{12}{|c|}{ PT Ades Waters Indonesia,Tbk } \\
\hline 2000 & 1,75 & 1,93 & $1.313,00$ & $110,28 \%$ & $45,41 \%$ & 0,92 & 1,43 & 10,00 & $2.300,00$ & $0,76 \%$ & 0,24 \\
\hline 2001 & $-8,35$ & 1,08 & $(135,00)$ & $-12,88 \%$ & $-4,94 \%$ & na & 1,61 & & $1.125,00$ & $0,00 \%$ & 0,46 \\
\hline 2002 & 7,45 & 0,63 & 97,00 & $8,51 \%$ & $3,57 \%$ & 0,05 & 1,38 & 2,00 & 725,00 & $2,06 \%$ & 0,55 \\
\hline 2003 & 22,14 & 0,86 & 46,00 & $3,90 \%$ & $1,83 \%$ & 0,02 & 1,13 & na & $1.025,00$ & na & 0,37 \\
\hline 2004 & $-2,28$ & 19,34 & $(99,00)$ & $(848,77)$ & $(144,04)$ & na & 4,86 & na & $2.257,00$ & na & 0,42 \\
\hline 2005 & $-2,08$ & $-2,83$ & $(797,00)$ & $135,67 \%$ & $-56,99 \%$ & na & na & $\mathrm{Na}$ & $1.660,00$ & na & 0,22 \\
\hline 2006 & $-1,29$ & \begin{tabular}{|l|}
$-0,77$ \\
\end{tabular} & $(860,00)$ & $59,44 \%$ & $(55,22)$ & na & na & $\mathrm{Na}$ & $1.110,00$ & na & 0,12 \\
\hline 2007 & $-2,78$ & 6,42 & $(263,00)$ & $(230,76)$ & $(86,62)$ & na & na & $\mathrm{Na}$ & 730,00 & na & 0,34 \\
\hline
\end{tabular}

PT Aqua Golden Mississipi,Tbk

\begin{tabular}{|r|r|r|l|l|l|l|l|l|l|l|l|l}
\hline 2000 & 4,79 & 1,49 & $2.922,00$ & $31,08 \%$ & $11,28 \%$ & 0,07 & 1,76 & 500,00 & $14.000,00$ & $17,11 \%$ & 0,71 & 9 \\
\hline 2001 & 9,59 & 2,79 & $3.548,00$ & $29,12 \%$ & $9,35 \%$ & 0,06 & 2,11 & 625,00 & $35.000,00$ & $17,13 \%$ & 0,68 & 4 \\
\hline 2002 & 7,47 & 2,24 & $5.023,00$ & $29,95 \%$ & $12,32 \%$ & 0,06 & 1,4 & 860,00 & $37.500,00$ & $17,12 \%$ & 1,31 & 1 \\
\hline 2003 & 9,95 & 2,33 & $4.805,00$ & $23,45 \%$ & $12,09 \%$ & 0,06 & 0,93 & 800,00 & $47.800,00$ & $16,65 \%$ & 5,08 & 2 \\
\hline 2004 & 6,89 & 1,78 & $6.962,00$ & $25,85 \%$ & $13,66 \%$ & 0,07 & 0,97 & $1.180,00$ & $48.000,00$ & $16,95 \%$ & 4,43 & 2 \\
\hline 2005 & 12,89 & 2,05 & $4.889,00$ & $15,88 \%$ & $8,79 \%$ & 0,04 & 0,78 & 830,00 & $63.000,00$ & $16,98 \%$ & 7,1 \\
\hline 2006 & 29,64 & 3,24 & $3.712,00$ & $10,92 \%$ & $6,14 \%$ & 0,03 & 0,77 & na & $110.000,00$ & na & 7,18 & 3 \\
\hline
\end{tabular}




\begin{tabular}{r|r|r|r|r|r|r|r|r|r|r|r|r|r|}
\hline 2007 & 25,86 & 3,36 & $5.008,00$ & $12,99 \%$ & $7,39 \%$ & 0,03 & 0,74 & $1.000,00$ & $129.500,00$ & $19,97 \%$ & 7,09 & 3 \\
\hline
\end{tabular}

\begin{tabular}{r|r|r|r|l|l|r|r|r|r|r|r|r|}
\hline 2000 & 7,64 & 3,33 & 4,45 & $43,57 \%$ & $21,66 \%$ & 0,18 & 1,02 & 817,00 & $34.000,00$ & $18,37 \%$ & 0,86 & 6 \\
\hline 2001 & 3,89 & 1,52 & 5,40 & $38,99 \%$ & $21,99 \%$ & 0,2 & 1,49 & $4.463,00$ & $21.000,00$ & $82,61 \%$ & 1,17 & 3 \\
\hline 2002 & 6,81 & 2,05 & 4,04 & $36,06 \%$ & $17,90 \%$ & 0,16 & 0,68 & $3.097,00$ & $27.500,00$ & $76,72 \%$ & 1,23 & 1 \\
\hline 2003 & 7,47 & 2,51 & 4,28 & $33,63 \%$ & $18,68 \%$ & 0,16 & 0,8 & $3.042,00$ & $32.000,00$ & $78,05 \%$ & 1,15 & 1 \\
\hline 2004 & 10,38 & 3,39 & 4,10 & $32,64 \%$ & $15,45 \%$ & 0,12 & 1,11 & $3.000,00$ & $42.500,00$ & $73,25 \%$ & 0,98 & 1 \\
\hline 2005 & 12,11 & 4,62 & 4,13 & $38,18 \%$ & $15,12 \%$ & 0,12 & 1,52 & $3.165,00$ & $50.000,00$ & $76,64 \%$ & 0,68 & 1 \\
\hline 2006 & 15,75 & 5,84 & 3,49 & $37,08 \%$ & $12,05 \%$ & 0,08 & 2,08 & $2.640,00$ & $55.000,00$ & $75,60 \%$ & 0,53 & 9 \\
\hline & 13,73 & 5,86 & 4,01 & $42,68 \%$ & $13,57 \%$ & 0,09 & 2,14 & $3.600,00$ & $55.000,00$ & $89,89 \%$ & 0,59 & 9 \\
\hline
\end{tabular}

\begin{tabular}{l|l|l|l|l|l|l|l|l|l|l|l|l}
\hline 2000 & 2,44 & 0,36 & 236,00 & $14,65 \%$ & $11,72 \%$ & 0,21 & 1,611 & 188,00 & 575,00 & $3 ., 66 \%$ & & 1 \\
\hline 2001 & 2,66 & 0,36 & 225,00 & $13,68 \%$ & $11,72 \%$ & 0,18 & 1,649 & 60,00 & 600,00 & $5,10 \%$ & \\
\hline 2002 & 3,28 & 0,41 & 228,00 & $10,97 \%$ & $12,57 \%$ & 0,14 & 0,15 & 70,00 & 750,00 & $7,09 \%$ & & 1 \\
\hline 2003 & 3,61 & 0,44 & 236,00 & $10, . . \%$ & & 0,14 & 0,19 & 92,00 & 850,00 & $6,86 \%$ & & 1 \\
\hline 2004 & 3,79 & 0,44 & 352,00 & & & & 0,22 & & & & & 1 \\
\hline 2005 & 5,47 & 0,77 & 366,00 & $14,16 \%$ & $11,53 \%$ & 0,15 & 0,23 & 100,00 & $2.000,00$ & $6,24 \%$ & & 2 \\
\hline 2006 & 5,54 & 0,76 & 397,00 & $13,78 \%$ & $11,00 \%$ & 0,14 & 0,25 & 100,00 & $2.200,00$ & $6,06 \%$ & & 2 \\
\hline 2007 & 4,32 & 0,64 & 486,00 & $14,89 \%$ & $11,71 \%$ & 0,14 & 0,27 & & $2.100,00$ & $5,41 \%$ & & 3 \\
\hline
\end{tabular}




\begin{tabular}{|c|c|c|c|c|c|c|c|c|c|c|c|}
\hline & & & & & & & & 125,00 & & & \\
\hline & & \multicolumn{10}{|c|}{ PT Fast Food Indonesia,Tbk } \\
\hline 2000 & 16,23 & 5,11 & 59,00 & $31,48 \%$ & $13,99 \%$ & 0,08 & 1,25 & 11,00 & 950,00 & $18,79 \%$ & 1,36 \\
\hline 2001 & 13,35 & 3,33 & 58,00 & $24,90 \%$ & $12,32 \%$ & 0,04 & 1,02 & 11,00 & 775,00 & $18,96 \%$ & 1,11 \\
\hline 2002 & 10,67 & 2,94 & 84,00 & & $15,41 \%$ & 0,05 & 0,79 & 16,00 & 900,00 & $18,96 \%$ & 1,33 \\
\hline 2003 & 11,38 & 2,49 & 81,00 & $32,87 \%$ & $12,93 \%$ & 0,05 & 0,69 & 16,00 & 925,00 & $19,68 \%$ & 1,27 \\
\hline 2004 & 13,07 & 2,41 & 80,00 & $28,43 \%$ & $11,11 \%$ & 0,04 & 0,66 & 18,00 & $1.050,00$ & $22,40 \%$ & 1,29 \\
\hline 2005 & 12,97 & 2,35 & 93,00 & $18,09 \%$ & $10,93 \%$ & 0,04 & 0,66 & 20,00 & $1.200,00$ & $21,61 \%$ & 1,14 \\
\hline 2006 & 11,78 & 2,82 & 154,00 & $23,92 \%$ & $14,25 \%$ & 0,05 & 0,68 & 20,00 & $1.820,00$ & $12,95 \%$ & 1,07 \\
\hline 2007 & 10,66 & 2,9 & 230,00 & $27,17 \%$ & $16,29 \%$ & 0,06 & 0,67 & 45,00 & $2.450,00$ & $19,58 \%$ & 1,28 \\
\hline
\end{tabular}

PT Indah Kiat Pulp\& Paper Corporation

\begin{tabular}{r|r|r|r|r|r|r|r|r|r|r|r|r|}
\hline 2000 & $-4,51$ & 0,76 & $(183,00)$ & $-16,88 \%$ & $-6,97 \%$ & 0,34 & 1,42 & & 825,00 & & 0,24 & 4 \\
\hline 2001 & $-3,78$ & 0,31 & $(83,00)$ & $-8,31 \%$ & $-3,23 \%$ & 0,18 & 1,55 & & 315,00 & & 0,22 & 4 \\
\hline 2002 & $-0,33$ & 0,05 & $(433,00)$ & $(13,82)$ & $(4,81)$ & na & $1,87 \%$ & na & 145,00 & na & 0,22 & 3 \\
\hline 2003 & $-1,3$ & 0,23 & $(442,00)$ & $(17,47)$ & $(5,26)$ & na & $2,32 \%$ & na & 575,00 & na & 0,22 & 2 \\
\hline 2004 & & & 63,00 & & & & & & & & & 3 \\
\hline 2005 & 74,75 & 0,29 & 14,00 & $0,39 \%$ & $0,15 \%$ & 0,02 & 1,57 & & $1.080,00$ & na & 3,09 & 3 \\
\hline 2006 & $-3,08$ & 0,31 & $(306,00)$ & $-9,98 \%$ & $-3,51 \%$ & 0,07 & 1,84 & & 940,00 & na & 1,67 & 3 \\
\hline 2007 & 5,31 & 0,25 & 158,00 & $4,71 \%$ & $1,67 \%$ & 0,12 & 1,82 & & 840,00 & na & 1,28 & 3 \\
\hline
\end{tabular}

PT Textile Manufacturing Company Jaya,Tbk (PT TEXMACO JAYA)

\begin{tabular}{|r|r|r|r|r|r|l|l|l|r|l|l|}
\hline 2000 & $-3,2$ & $-2,91$ & $(938,00)$ & $-91,03 \%$ & $-28,29 \%$ & na & na & & $3.000,00$ & & 0,41 \\
\hline 2001 & $-4,16$ & $-1,69$ & $(710,00)$ & $-40,77 \%$ & $-22,01 \%$ & na & na & & $2.950,00$ & & 0,38 \\
\hline 2002 & $-7,39$ & $-0,68$ & $(399,00)$ & $-9,21 \%$ & $-55,13 \%$ & na & na & na & $2.950,00$ & $\mathrm{Na}$ & 0,04 \\
\hline 2003 & $-32,53$ & $-0,67$ & $(91,00)$ & $-2,05 \%$ & $65,48 \%$ & na & na & na & $2.950,00$ & $\mathrm{Na}$ & 0,04 \\
\hline 2004 & $-14,67$ & $-0,64$ & $(201,00)$ & $-4,35 \%$ & $73,00 \%$ & na & na & na & $2.950,00$ & $\mathrm{Na}$ & 0,03 \\
\hline 2005 & $-6,32$ & $-1,34$ & $(467,00)$ & $-21,16 \%$ & $-15,60 \%$ & na & na & na & $2.950,00$ & $\mathrm{Na}$ & 0,42 \\
\hline 2006 & $-5,98$ & $-1,09$ & $(494,00)$ & $18,27 \%$ & $-30,25 \%$ & na & na & na & $2.950,00$ & $\mathrm{Na}$ & 0,34 \\
\hline 2007 & $-5,6$ & $-0,84$ & $(524,00)$ & $-14,97 \%$ & $-41,08 \%$ & na & na & na & $2.950,00$ & $\mathrm{Na}$ & 0,22 \\
\hline
\end{tabular}

PT Roda Vivatex,Tbk 


\begin{tabular}{|r|r|r|r|r|r|r|r|r|r|r|r|r|}
\hline 2000 & 11,71 & 1,09 & 90,00 & $9,32 \%$ & $7,60 \%$ & 0,12 & 0,23 & 18,00 & $1.050,00$ & $19,52 \%$ & 3,93 \\
\hline 2001 & 45,63 & 1,21 & 26,00 & $2,65 \%$ & $2,28 \%$ & 0,03 & 0,16 & na & $1.175,00$ & $\mathrm{Na}$ & 3,99 \\
\hline 2002 & $-29,49$ & 1,06 & $(34,00)$ & $-3,60 \%$ & $-3,02 \%$ & na & 0,19 & na & $1.000,00$ & $\mathrm{Na}$ & 2,85 \\
\hline 2003 & 36,22 & 0,93 & 25,00 & $2,58 \%$ & $2,16 \%$ & 0,02 & 0,2 & $\mathrm{na}$ & 900,00 & $\mathrm{Na}$ & 3,79 \\
\hline 2004 & 19,14 & 0,82 & 43,00 & $4,28 \%$ & $3,59 \%$ & 0,07 & 0,19 & $\mathrm{na}$ & 825,00 & $\mathrm{Na}$ & 2,23 \\
\hline 2005 & 10,56 & 0,76 & 79,00 & $7,16 \%$ & $5,79 \%$ & 0,13 & 0,24 & $\mathrm{na}$ & 830,00 & $\mathrm{na}$ & 1,2 \\
\hline 2006 & 7,39 & 0,76 & 130,00 & $10,19 \%$ & $6,48 \%$ & 0,25 & 0,57 & na & 960,00 & $\mathrm{na}$ & 0,85 \\
\hline 2007 & 10,11 & 0,94 & 130,00 & $9,30 \%$ & $5,97 \%$ & 0,25 & 0,56 & na & $1.310,00$ & $\mathrm{na}$ & 0,82 \\
\hline
\end{tabular}

PT Panasia Indosyntec Tbk

\begin{tabular}{|c|c|c|c|c|c|c|c|c|c|c|c|}
\hline 2000 & $-1,87$ & 3,03 & $(441,00)$ & $-161,87 \%$ & $-9,92 \%$ & na & 15,32 & & 825,00 & & 0,7 \\
\hline 2001 & $-2,65$ & 0,65 & $(77,00)$ & $-24,59 \%$ & $-1,79 \%$ & na & 12,75 & & 205,00 & & 0,6 \\
\hline 2002 & 1,04 & 0,38 & 191,00 & $36,84 \%$ & $5,07 \%$ & 0,09 & 6,18 & na & 200,00 & na & 1,18 \\
\hline 2003 & $-0,5$ & 0,59 & $(55,00)$ & $-11,84 \%$ & $-1,57 \%$ & na & 6,44 & na & 275,00 & na & 1,03 \\
\hline 2004 & $-16,08$ & 0,97 & $(31,00)$ & $-6,01 \%$ & $1,49 \%$ & na & 3,04 & na & 500,00 & na & 1,06 \\
\hline 2005 & 3,48 & 0,72 & 556,00 & $20,70 \%$ & $8,39 \%$ & 0,1 & 1,47 & na & 400,00 & na & 1,02 \\
\hline 2006 & 1269,49 & 0,67 & 600,00 & $0,05 \%$ & $0,03 \%$ & na & 0,89 & na & 400,00 & na & 1 \\
\hline 2007 & 446,14 & 0,66 & 603,00 & $0,21 \%$ & $0,11 \%$ & na & 0,88 & na & 400,00 & na & 1,13 \\
\hline
\end{tabular}

\section{PT Panasia Filament Inti Tbk}

\begin{tabular}{r|r|r|r|r|r|r|r|l|r|r|r|r|}
\hline 2000 & $-1,07$ & 1,18 & $(375,00)$ & $-110,64 \%$ & $-9,88 \%$ & na & 10,2 & na & 400,00 & na & 0,75 & c \\
\hline 2001 & $-0,78$ & 0,48 & $(225,00)$ & $-61,08 \%$ & $-6,12$ & na & 8,97 & na & 175,00 & na & 1,09 & $c$ \\
\hline 2002 & 1,01 & 0,2 & 99,00 & $19,62 \%$ & $3,18 \%$ & 0,04 & 5,34 & na & 100,00 & na & 1,65 & $c$ \\
\hline 2003 & $-0,47$ & 0,24 & $(170,00)$ & $-50,70 \%$ & $-5,92 \%$ & na & 7,56 & na & 80,00 & na & 1,21 & $c$ \\
\hline 2004 & 0,42 & 0,24 & $(238,00)$ & $-57,58 \%$ & $-8,37 \%$ & na & 5,88 & na & 100,00 & na & 1,37 & $c$ \\
\hline 2005 & $-1,79$ & 0,89 & $(39,00)$ & $-49,56 \%$ & $-4,93 \%$ & na & 9,06 & na & 70,00 & na & 1,04 & $c$ \\
\hline 2006 & $-1,19$ & 0,36 & $(34,00)$ & $-24,04 \%$ & $-6,44 \%$ & na & 2,73 & na & 40,00 & na & 1,08 & $c$ \\
\hline 2007 & $-7,18$ & 3,31 & $(35,00)$ & $-46,03 \%$ & $-9,25 \%$ & na & 3,97 & na & 250,00 & na & 1,15 & $c$ \\
\hline
\end{tabular}

PT Eratex djaya Tbk

\begin{tabular}{r|r|r|r|r|r|r|r|r|r|r|r|r|}
\hline 2000 & 7,85 & 0,63 & 54,00 & $8,08 \%$ & $1,03 \%$ & 0,01 & 6,82 & 25,00 & 425,00 & $46,15 \%$ & 1,88 & 0 \\
\hline 2001 & 6,28 & 0,59 & 67,00 & $9,40 \%$ & $1,43 \%$ & 0,01 & 5,57 & 15,00 & 420,00 & $22,42 \%$ & 2,24 & 0 \\
\hline 2002 & 4,58 & 0,27 & 44,00 & $5,87 \%$ & $1,02 \%$ & na & 4,65 & 10,00 & 200,00 & $22,91 \%$ & 1,93 & $c$ \\
\hline
\end{tabular}




\begin{tabular}{|l|r|r|r|r|r|r|r|l|l|l|l|l|}
\hline 2003 & $-0,44$ & 0,86 & $(479,00)$ & $-196,36 \%$ & $-16,22 \%$ & na & 10,96 & na & 210,00 & na & 1,35 & 0 \\
\hline 2004 & $-0,31$ & $-9,35$ & $(256,00)$ & $1852,50 \%$ & $-8,44 \%$ & 0,02 & na & na & 130,00 & na & 1,12 & $c$ \\
\hline 2005 & $-0,6$ & 0,68 & $(167,00)$ & $-113,05 \%$ & $-5,50 \%$ & na & $-21,36$ & na & 100,00 & na & 0,79 \\
\hline 2006 & $-2,27$ & 0,73 & $(62,00)$ & $-32,17 \%$ & $-1,97 \%$ & na & $-17,33$ & na & 140,00 & na & 0,78 \\
\hline 2007 & $-7,43$ & 0,82 & $(26,00)$ & $-11,07 \%$ & $-0,86 \%$ & na & $-13,86$ & na & 190,00 & na & 0,69 & \\
\hline
\end{tabular}

PT Century Textile Industry (Centex) tbk

\begin{tabular}{|c|c|c|c|c|c|c|c|c|c|c|c|}
\hline 2000 & 1,79 & 0,33 & $2.792,00$ & $18,39 \%$ & $13,27 \%$ & 0,11 & 0,39 & & $5.000,00$ & & 3,12 \\
\hline 2001 & 2,92 & 0,3 & $1.714,00$ & $10,40 \%$ & $6,99 \%$ & 0,07 & 0,49 & & $5.000,00$ & & 1,87 \\
\hline 2002 & 0,26 & 0,03 & $1.714,00$ & $10,40 \%$ & $6,99 \%$ & 0,07 & 0,49 & na & 450,00 & na & 1,87 \\
\hline 2003 & 257,76 & 0,02 & 1,00 & $0,02 \%$ & $0,01 \%$ & na & 0,82 & na & 290,00 & na & 1,12 \\
\hline 2004 & 105,45 & 1,23 & 45,00 & $0,04 \%$ & $0,04 \%$ & na & 1,2 & na & $4.700,00$ & na & 0,97 \\
\hline 2005 & 2,43 & 0,23 & $1.442,00$ & $9,54 \%$ & $4,28 \%$ & 0,05 & 1,23 & na & $3.500,00$ & na & 0,84 \\
\hline 2006 & $-1,34$ & 0,08 & $(1.979,00)$ & $-15,13 \%$ & $-5,06 \%$ & na & 1,99 & na & $2.650,00$ & na & 1,4 \\
\hline 2007 & $-0,7$ & 0,11 & $(3.780,00)$ & $-40,65 \%$ & $-8,90 \%$ & na & 3,57 & na & $2.650,00$ & na & 1,03 \\
\hline
\end{tabular}

PT Argo Pantes Tbk

\begin{tabular}{r|r|r|r|r|r|l|l|l|r|r|r|r}
\hline 2000 & $-0,88$ & $-0,96$ & $(1.599,00)$ & $-109,20 \%$ & $-16,03 \%$ & na & na & na & $1.400,00$ & & 0,22 &. \\
\hline 2001 & $-1,42$ & $-0,43$ & $(633,00)$ & $-30,22 \%$ & $-6,18 \%$ & na & na & na & 900,00 & & 0,23 &. \\
\hline 2002 & 0,34 & 15,03 & $2.062,00$ & $4428,54 \%$ & $24,10 \%$ & na & na & na & 700,00 & na & 0,34 &. \\
\hline 2003 & 23,06 & 190,5 & 56,00 & $826,13 \%$ & $0,70 \%$ & na & na & na & $1.300,00$ & na & 0,29 &. \\
\hline 2004 & $-1,5$ & 1,57 & $(881,00)$ & $-104,21 \%$ & $-13,26 \%$ & na & na & na & $1.325,00$ & na & 0,32 &. \\
\hline 2005 & $-1,61$ & $-1,8$ & $(809,00)$ & $-99,38 \%$ & $-10,96 \%$ & na & na & na & $1.300,00$ & na & 0,29 &. \\
\hline 2006 & $-19,31$ & $-2,44$ & $(67,00)$ & $-12,62 \%$ & $-0,91 \%$ & na & na & na & $1.300,00$ & na & 0,3 &. \\
\hline 2007 & $-2,31$ & 1,45 & $(564,00)$ & $-59,49 \%$ & $-9,60 \%$ & na & na & na & $1.300,00$ & na & 0,56 & . \\
\hline
\end{tabular}

\section{Sumber: data diolah}

Penilaian Saham dengan metode Benjamin Graham 
1. Memilih saham berfundamental kuat dengan melakukan Screening sebagai berikut:

a. Sektor

Seluruh saham kecuali saham teknologi $\geq$ Pilih

Saham-saham teknologi < Buang

b. Revenue. Untuk mengurangi risiko, Graham merekomendasikan untuk berinvestasi pada perusahaan dengan revenue tahunan minimal $\$ 50$ juta atau untuk kondisi saat ini setara dengan \$340 juta. Untuk di Indonesia kapitalisasi pasar rata-rata perusahaan di BEI adalah \$576 juta. Dengan membandingkan kapitalisasi rata-rata perusahaan di BEI terhadap NYSE, maka revenue minimal untuk penyesuaian kriteria Graham untuk BEI adalah sebesar (\$576 juta/\$10.3 miliar) x \$340 juta, atau sekitar \$19 juta. Jika kita nyatakan dalam Rupiah, nilai tersebut setara dengan Rp 175 miliar.

Revenue:

$\geq$ Rp 175 miliar $\rightarrow$ Pilih

$<$ Rp 175 miliar $\rightarrow$ Buang

c. Current Ratio. Graham menyukai perusahaan dengan likuiditas yang tinggi sehingga risiko terkena permasalahan keuangan menjadi semakin kecil. Salah satu parameter yang bisa digunakan untuk mengukur tingkat likuiditas adalah current ratio (current assets / current liabilities).

Current Ratio $\geq 2 \rightarrow$ Pilih

Current ratio $<2$ dan perusahaan utilitas atau telekomunikasi $\rightarrow$ Pilih Current ratio $<2$ untuk perusahaan selain itu $\rightarrow$ Buang

d. Utang Jangka Panjang tehadap Net Current Assets. Graham tidak menyukai perusahaan yang utangnya terlalu besar. Yang dimaksud dengan net current assets adalah current asset dikurangi dengan current liabilities atau biasa disebut juga dengan working capital (modal kerja)

e. Pertumbuhan EPS Jangka Panjang. Walaupun Graham adalah pelopor value investing namun growth tetap berperan penting dalam pemilihan sahamnya. Berbeda dengan growth investing, Graham menggunakan pertumbuhan EPS (Earning per Share) masa lalu untuk memperkirakan 
pertumbuhan EPS di masa datang. Dengan kata lain, pertumbuhan EPS sebagai indikator kestabilan keuangan suatu perusahaan. Dengan menggunakan data selama 10 tahun ke belakang sebagai acuan.

f. P/E Ratio (Price to Earning Ratio). Rasio ini digunakan untuk membandingkan harga wajar suatu saham terhadap harga yang diberikan oleh pasar.

g. P/BV Ratio (Price to Book Ratio). Rasio lain yang digunakan untuk membandingkan harga wajar saham dengan harga di pasar adalah P/BV ratio. Graham berpendapat bahwa perkalian antara $\mathrm{P} / \mathrm{BV}$ ratio dengan $\mathrm{P} / \mathrm{E}$ ratio tidak boleh melebihi 22 .

h. Total D/E Ratio (Debt to Equity Ratio). Secara umum, total utang perusahaan baik jangka pendek maupun jangka panjang tidak boleh melebihi nilai ekuitasnya. Untuk perusahaan utilitas, telekomunikasi, dan jalan raya yang perlu diperhatikan adalah Long Term Debt to Equity Ratio saja karena adanya earning power.

i. Konsistensi Pembayaran Dividen. Graham sangat menyukai perusahaan yang membayarkan dividen secara terus-menerus selama 20 tahun terakhir berapapun jumlahnya.

2. Menentukan harga wajar dapat digunakan formula yang telah ditemukan Graham sebagai berikut:

$$
\mathrm{V}=\operatorname{EPS} \times(8.5+2 \mathrm{G}) \times(6.5 / \mathrm{AAA})
$$

Adapun hasil perhitungannya adalah sebagai berikut:

Tabel 2

Hasil perhitungan Metode Benjamin Graham

\begin{tabular}{|l|l|l|}
\hline \multicolumn{1}{|c|}{ Nama Perusahaan } & \multicolumn{1}{|c|}{ Perhitungan } & \multicolumn{1}{c|}{ Nilai V } \\
\hline PT Ades WatersIndonesia,Tbk & $-0.417 \times[8.5+(2 \times 115)] \times(6.5 / 11,625)$ & $5.560,89$ \\
PT Aqua Golden Mississipi,Tbk & $3.879 \times[8.5+(2 \times 115)] \times(6.5 / 11,625)$ & $51.728,4$ \\
PT Multi Bintang Indonesia,Tbk & $1.373 \times[8.5+(2 \times 115)] \times(6.5 / 11,625)$ & $18.309,61$ \\
PT Lion Metal Works,Tbk & $.648 \times \times[8.5+(2 \times 115)] \times(6.5 / 11,625)$ & $8.641,39$ \\
PT Fast Food Indonesia,Tbk & $1.599 \times \times[8.5+(2 \times 115)] \times(6.5 / 11,625)$ & $21.323,44$ \\
PT Indah Kiat Pulp\& Paper Corp. & $0.7965 \times \times[8.5+(2 \times 115)] \times(6.5 / 11,625)$ & $10.621,71$ \\
PT Textile Manufacturing & $-0.56 \times \times[8.5+(2 \times 115)] \times(6.5 / 11,625)$ & $7.467,87$ \\
\hline
\end{tabular}


Company Jaya,Tbk

PT Roda Vivatex,Tbk

$1.011 \times \times[8.5+(2 \times 115)] \times(6.5 / 11,625)$

243,76

PT Panasia Indosyntec Tbk

Eratex djaya Tbk

PT Century Textile Industry

$-0.718 \times \times[8.5+(2 \times 115)] \times(6.5 / 11,625)$

$9.574,88$

$-1.1145 \times$ x $[8.5+(2 \times 115)] \times(6.5 / 11,625)$

$14.862,39$

$-0.105 \times$ x $[8.5+(2 \times 115)] \times(6.5 / 11,625)$

1400,23

$-0.3465 \times \mathrm{x}[8.5+(2 \times 115)] \mathrm{x}$

$4.620,75$

PT Argo Pantes Tbk

$(6.5 / 11,625)$

Berdasarakan perhitungan diatas maka kita dapat mengetahui harga saham dalam kondisi overvalue dan under value apabilah harga intrinsic diatas berada di bawah atau di atas harga pasar saham.

\section{Penilaian Saham dengan Gordon Model}

Salah satu pendekatan dalam menentukan harga wajar saham adalah dengan mengunakan model Gordon Growth (Gordon Growth Model) . Model ini pertama kali dikembangkan oleh Gordon seorang pakar dibidang keuangan perusahaan. Model penilaian saham ini menyatakan bahwa nilai wajar suatu saham adalah nilai sekarang dari penjumlahan arus kas yang diharapkan diterima pemegang saham pada masa datang. Arus kas tersebut didiskontokan dengan menggunakan tingkat biaya modal (cost of capital) yang mencerminkan adanya tingkat pengembalian saham yang bersangkutan. Mengingat arus kas yang diterima oleh pemegang saham dalam bentuk deviden maka nilai wajar saham menunjukkan nilai sekarang dari seluruh deviden yang akan dibayar perusahaan tersebut pada masa dating.

Tabel 3

Faktor Pertumbuhan dalam Model Gordon

\begin{tabular}{|l|l|l|l|l|c|}
\hline $\begin{array}{c}\text { EPS/MktPr } \\
\text { Aktual }\end{array}$ & & $\begin{array}{c}\text { Laba } \\
\text { Ditahan(\%) }\end{array}$ & & \multicolumn{1}{|c|}{$\begin{array}{c}\text { Besar } \\
\text { Pertumbuhan }\end{array}$} & Penjelasan \\
\hline 0 & & 0 & & Tidak ada & $\begin{array}{c}\text { Tidak ada laba yang } \\
\text { ditahan }\end{array}$ \\
\hline 0.05 & & 0 & & Tidak ada & $\begin{array}{c}\text { Semua laba dibagikan } \\
\text { sebagai dividend. }\end{array}$ \\
\hline 0.05 & $\mathrm{X}$ & 0.50 & $=$ & 0.025 & \\
\hline 0.10 & $\mathrm{X}$ & 0.50 & $=$ & 0.050 & Pertumbuhan meningkat \\
\hline
\end{tabular}




\begin{tabular}{|l|l|l|l|l|c|}
\hline & & & & & $\begin{array}{c}\text { seiring dengan kenaikan } \\
\text { laba. }\end{array}$ \\
\hline 0.10 & $\mathrm{X}$ & 0.60 & $=$ & 0.060 & $\begin{array}{c}\text { Pertumbuhan meningkat } \\
\text { seiring dengan laba } \\
\text { ditahan yang semakin } \\
\text { tinggi. }\end{array}$ \\
\hline
\end{tabular}

Tabel 4

Perbandingan Nilai Intrinsik Menurut Model Gordon Untuk Tingkat Pengembalian dan Dividend payouts Yang Berbeda

\begin{tabular}{|l|l|l|l|}
\hline & \multicolumn{3}{|c|}{$\begin{array}{c}\text { Tingkat Pengembalian Minimal } \\
\text { Capitalization Rate Required }\end{array}$} \\
\hline $\begin{array}{l}30 \% \\
\text { dividend } \\
\text { payout }\end{array}$ & $\frac{R p 0.60}{8 \%-(10 \% \times 70 \%)}=R p 60.00$ & $\frac{R p 0.60}{10 \%-(10 \% \times 70 \%)}=R p 20.00$ & $\frac{R p 0.60}{12 \%-(10 \% \times 70 \%)}=R p 12.00$ \\
\hline $\begin{array}{l}50 \% \\
\text { dividend } \\
\text { payout }\end{array}$ & $\frac{R p 1.00}{8 \%-(10 \% \times 50 \%)}=R p 33.33$ & $\frac{R p 1.00}{10 \%-(10 \% \times 50 \%)}=R p 20.00$ & $\frac{R p 1.00}{12 \%-(10 \% \times 50 \%)}=R p 14.29$ \\
\hline $\begin{array}{l}70 \% \\
\text { dividend } \\
\text { payout }\end{array}$ & $\frac{R p 1.40}{8 \%-(10 \% \times 30 \%)}=R p 28.00$ & $\frac{R p 1.40}{10 \%-(10 \% \times 30 \%)}$ & \\
\hline $\begin{array}{l}100 \% \\
\text { dividend } \\
\text { payout }\end{array}$ & $\frac{R p 2.00}{8 \%-(10 \% \times 0 \%)}=R p 25$ & $\frac{R p 2.00}{10 \%-(10 \% \times 0 \%)}=R p 20.00$ & $\frac{R p 1.40}{12 \%-(10 \% \times 0 \%)}=R p 16.67$ \\
\hline
\end{tabular}

Catatan: Semua data pada perusahaan dengan EPS $=$ Rp2 dan tingkat pengembalian modal sendiri (return on equity) $=10 \%$.

Berdasarkan analisis data, maka dapat di buat suatu keputusan bahwa ketiga metode yang terdiri dari analisis fundamental, metode Gordon, dan metode Benjamin dalam menentukan harga wajar saham bias dikombinasikan ketiga metode tersebut karena ketiga metode saling menunjang dan menjanjikan harga saham yang wajar atau mendekati harga intrinsiknya.

\section{KESIMPULAN}


Berdasarkan hasil analisis pada bab sebelumnya maka dapat disimpulkan bahwa untuk menentukan nilai wajar saham dapat digunakan pendekatan fundamental dan analisis tehnikal. Pada dasarnya yang sering digunakan untuk mengetahui nilai wajar saham yaitu menggunakan pendekatan fundamental dengan melihat nilai dari EPS, PER, dan PBV akan dibandingkan dengan nilai intrinsiknya. Apabila diketahui nilai intrinsik lebih kecil dibanding harga pasar, maka saham dalam kondisi under value sedangkan sebaliknya bila nilai intrinsiknya lebih besar dibanding dengan nilai pasarnya, maka saham dalam kondisi over value.

Dari beberapa rasio yang digunakan dapat disimpulkan bahwa secara fundamental saham dapat diketahui bahwa kapan saham dalam kondisi overvalue dan kapan dalam kondisi undervalue. Selain pendekatan fundamental dapat pula digunakan pendekatan yang lain yaitu pendekatan tehnikal, tetapi hal ini kurang begitu disukai investor sehingga pendekatan fundamental lebih banyak digunakan untuk mengetahui harga saham dalam kondisi over dan under value.

Selain pendekatan diatas dapat pula digunakan pendekatan fundamental yang lain yaitu Gordon yang memperhitungkan adanya pertumbuhan dividen, bagi perusahaan yang membagikan dividen harga sahamnya akan mendekati nilai intrinsiknya sedangkan metode yang dikenalkan Benyamin untuk menentukan harga wajar saham, lebih memperhatikan kehati-hatian sehingga untuk perusahaan yang mempunyai criteria tertentu yang telah disebutkan dalam bab sebelumnya nilai sahamnya mendekati nilai intrinsic. Dari ketiga metode dapat dikombinasikan supaya investor dapat mendapatkan harga saham yang betul-betul wajar atau mendekati nilai intrinsiknya untuk melakukan pembelian dan akan menjual sahamnya apabila harga pasar lebih tinggi disbanding nilai intrinsiknya.

\section{DAFTAR PUSTAKA}

Arief Sritua. 1993. Metodologi Penelitian Ekonomi. Cetakan Pertama. Penerbit Jakarta: Universitas Indonesia (UI-Press).

Asril Sitompul, 2000. Pasar Modal: Penawaran Umum dan Permasalahannya; Bandung: Citra Aditya. 
Balsam,Steven dan Lipka Roland.1998. Shares Price and Alternatif Measuring of Earning Pershare, American Accounting Association Accounting, Accounting Horizon Vol.12 No 13 Sep 1998

Beaver, William H.,1989, Financial Reporting, An Accounting Revaluation, Prentice Hall, 6

Eddy.A,\& Seifert. B.1992. Stock Price Reactions to Devidend and Earnings Announcements: Contempo-raneous Versus Noncontemporaneous Announcements, The Journal of Financial Research. Vol 15(3) 207-217

Fabozzi,F.1995. Investmens and Management,First Editi-on.USA:PrenticeHall,Inc.

Franchise,Jack Clark. 1996 Investment Analysis and Management, Fourt Edition, New York: Mc.Graw-Hill Inc,

Jorne,J.C.V \& Wachowicz,J.M.Jr.1999. Prinsip-prinsip Manajemen Keuangan, Edisi Bahasa Indonesia, Edisi kesembilan. Jakarta: Penerbit Salemba Empat.

Husnan S, Enny Pudjiastuti.1993. Dasar-dasar Teori Por-tofolio dan Analisis Investasi; Edisi Pertama, Yogyakarta: Penerbit UPP-AMP YKPN.

- 1996. Dasar-dasar Teori Portofolio dan Analisis Sekuritas,Edisi kedua, Yogyakarta: AMP YKPN.

Jigiyanto.2000.Teori Portofolio dan Anallisis Investasi. Yogyakarta: Edisi 3.BPFE.

Jones.P.Charles.1997.Investmen:Analysis and Management.Sixth Edition.North Carroline State Uni-versity.Torronto.USA

Jurnal Pasar Modal Indonesia,No.12/IX/Desember 1998

Martin,J.D.Koewn, A.J.Petty J.J.dan Scott Jr. D.F. 1985. Basic Financial Management. Fifth Edition. Prentice-Hall. Inc. USA. Diterjemahkan oleh Haris Munandar. 1993. Jakarta: Penerbit Rajawali.

Mekherji.S,Dhatt.S.M,Kim.H.Y.1997I. Financial Analysis Journal.

Mulyono Sugeng.2000. Pengaruh Earning Per Share (EPS) dan tingkat Bunga terhadap Harga Saham. Jurnal Ekonomi dan Manajemen, Vol.1.(2)99-115

Nai'im,A.1997. Peran Pasar Modal Dalam Pembangunan Ekonomi Indonesia. Jurnal Kelola, Edisi No.14/VI Hal.1-17

Porman Tambunan,Andi,2008. Menilai Harga Wajar Saham (stock valuation). cetakan kelima. Jakarta: PT.Gramedia

Quirin.J.J,Berry.K.T, and Bryan.D.O.2000. Fundamental Analysis Approach to Oil and Gas Firm Valuation. Journal of Business Finance \& Accounting, 27(7) $\&(8) 785-818$.

Sartono A.2005.Manajemen Keuangan;Edisi ketiga. Yogyakarta: BPFE.

Sharpe W.F,Henry Njooliangtik.1997. Investasi;Edisi Indonesia. Prehallindo, Jakarta. 
Sykes.A.T,2000 Valuable Goods (Union Heritage's Derek Batts Picuks Stocks that value with Grouwth), Black Enterprice,www.blackenterprice.com

Warsono.2000.Analisis Investasi dan Manajemen portofolio (Keputusan Investasi pada Sektor Sekuritas dan Pasar Modal),Edisi Pertama, Cetakan Pertama. Malang: UMM Press.

Widiatmojo,S.1995. Memetik Keuntungan di Bursa Efek: Kajian Peristiwa Penting Saat Pasar Bullish, Jakarta: Aneka Cipta.

1996.Cara Sehat Investasi di Pasar Modal, Cetakan ketiga Jakarta: Penerbit PT. Jurnalindo Alsara Grafika. 